\title{
Macronutrients Analysis of Porang Tubers (Amorphophallus muelleri Blume) Fermentation With Lactobacillus Bulgaricus Bacteria
}

\author{
Nur'aini ${ }^{1,4 *}$ Intan Wulan Dari ${ }^{2}$ Abdul Aziz Setiawan ${ }^{3,5}$ Dian Ratih Laksmitawati ${ }^{6}$ \\ ${ }^{1,2,3}$ Muhammadiyah College of Pharmacy Tangerang \\ 4,5 Pharmaceutical Science Doctoral Programme - Faculty of Pharmacy Pancasila University \\ ${ }^{6}$ Faculty of Pharmacy - Pancasila University \\ *Corresponding author.Email: nuraini.apt@stfm.ac.id
}

\begin{abstract}
Indonesia has various types of tubers offered to be developed, one of which is porang tuber (Amorphophallus muelleri Blume). Amorphophallus muelleri Blume has macronutrient content. Macronutrients consist of carbohydrates, starches, fiber, glucomannan, protein, and lipid. Porang tubers have higher glucomannan content applied in the food sector including emulsifiers and stabilizers based on the application in the pharmaceutical field. This research is a research on the exploitation by fermentation using Lactobacillus bulgaricus bacteria. Porang tuber fermentation (Amorphophallus muelleri Blume) with Lactobacillus bulgaricus bacteria contains carbohydrates, starch, fiber, glucomannan, protein, and lipid. Macronutrient levels were tested in accordance with SNI (National Standard of Indonesia) 1992. The results of the research on macronutrient content before fermentation and after fermentation for 8 hours, 10 hours and 12 hours for carbohydrates were mean \pm SD 3.80; starch mean \pm SD 2.83; fiber mean \pm SD 2.07 ; glucomannan mean \pm SD 12.77; protein mean \pm SD 2.41 ; and Lipid mean \pm SD 1.89 .
\end{abstract}

Keywords: Amorphophallus muelleri Blume, macronutrients, fermentation, lactobacillus bulgaricus

\section{INTRODUCTION}

Indonesia has various types of tubers, which are potential to be developed. One of which is Porang (Amorphophallus muelleri Blume). Porang is a plant that belongs to the Araceae family, and can optimally grow in areas with an altitude of 100 to $600 \mathrm{~m}$ above sea level [1]. Amorphophallus is known in two types, namely Amorphophallus variability (Amorphophallus oncophyllus, Amorphophallus muelleri Blume) and Amorphopallus campanulatus[2]. Amorphopallus muelleri Blume has a high glucomannan content and has been used as a source of carbohydrates and industrial raw materials, particularly by the food industry [3]. This plant can be used as an alternative food ingredient since it has a starch content of $76.5 \%, 9.20 \%$ protein, $25 \%$ fiber, $0.20 \%$ lipid, and contains glucomannan compounds and oxalic acid crystals which are relatively high [4]. Glucomannan is a water-soluble non-starch polysaccharide which is known as water-soluble fiber. Glucomannan can lower blood cholesterol levels and blood sugar levels, lose weight, and affect intestinal activity and immune system function [5]. Macronutrients are needed by the body in large quantities to provide energy for the body. Macronutrient levels can be changed by the fermentation process [6]. Fermentation is a hereditary method used in food processing to increase storability, palatability, digestibility, and nutritional value [7]. One of the most common ferments is milk fermentation which utilizes acid Lactobacillus sp. Bacteria[8].

Lactobacillus bulgaricus is a gram-positive probiotic bacterium which is classified as a homofermentative bacteria in the form of a rod [9]. Fermentation with Lactobacillus sp. can convert glucose to produce lactic acid as the only product. Lactic acid fermentation makes glucose levels decrease and can improve nutritional quality, organoleptic, and a preservative and detoxifying effect in food [8]. These provide a safe result for food products of fermented lactic acid bacteria and others [10].

\section{TOOL AND MATERIAL}

\subsection{Tool}

The tools use in this study comprise of Mesh 60, distiller, soxhletation device, titration instrument, stirring rod, blender, Buchner funnel, ovens, electric heaters, upright coolers, water baths and spectrophotometers.

\subsection{Material}

The research material used was porang tubers from Dukuh Pandean RT.17 RW.05 Banjarsariwetan Village, Dagang District, Madiun Regency. Pure culture of Lactobacillus bulgaricus bacteria obtained from PUSPIPTEK, aquadest, boric acid, hydrochloric acid (Merck), sulfuric acid (Merck), a mixture of selen, ethanol 
(Merck), aluminum sulfate salt, hexane (Merck), pp indicator, isopropyl alcohol (Merck) and sodium hydroxide (Merck).

\section{RESEARCH METHOD}

\subsection{Fermentation of Porang Tubers}

Porang tuber skin was peeled and washed with running water. Then, the tubers were sliced to ease the fermentation process. Fermentation was conducted by adding $2.3 \mathrm{~kg}$ of porang tuber slices. A container containing sterile aquadest inoculated with LAB inoculum stock of $3.5 \mathrm{~L}$ or 108 cells $/ \mathrm{ml}$, then incubated at $35^{\circ} \mathrm{C}$ for 8,10 , and 12 hours.

\subsection{Flour Making}

The tubers' dregs were taken and dried in an oven at 50 ${ }^{\circ} \mathrm{C}$ for 16 hours. After drying, the tuber slices were ground into a powder and sieved with a 60 mesh sieve.

\subsection{Macronutrient analysis}

\subsubsection{Carbohydrate levels}

The simplest determination of carbohydrates is through a rough calculation (proximate analysis) or carbohydrate by difference. Proximate analysis is an analysis in which the content of carbohydrates, including crude fiber, is identified not through analysis but by calculating:

$\%$ carbohydrates $=100 \%-\%($ protein + fat + ash + water $)$

\subsubsection{Analysis of Starch Levels}

The starch analysis was utilizing the spectrophotometric method. A total of 3 grams of fermented porang flour was washed using $80 \%$ ethanol, as much as $\pm 30 \mathrm{ml}$ in order to remove simple sugars at room temperature for 15 minutes. Furthermore, the simple sugar removal process was performed. A total of $0.5 \mathrm{~g}$ of fermented simple sugar porang flour samples were weighed and put into Erlenmeyer. Furthermore, the analysis process used the DNS method. Moreover, the absorbance was observed with a spectrophotometer at a wavelength of $\lambda=540 \mathrm{~nm}$; the starch content was determined by connecting the absorbance value with the standard curve of glucose solution.

\subsubsection{Fiber Content Analysis}

The step include carefully weigh $2 \mathrm{~g}$ of the sample ; pat dry and add to $500 \mathrm{ml}$ Erlenmeyer; add $50 \mathrm{ml}$ of $1.25 \%$ $\mathrm{H}_{2} \mathrm{SO}_{4}$ solution; then simmer for 30 minutes using an upright cooler; add $50 \mathrm{ml}$ of $3.25 \% \mathrm{NaOH}$ and simmer for another 30 minutes. When it was hot, filter it with a Buchner funnel containing filter paper which weight has been identified. It is needed wash the sediment on the filter paper with $1.25 \% \mathrm{H}_{2} \mathrm{SO}_{4}$, hot water, and $96 \%$ ethanol. Moreover the filter paper and its contents, dry at $105^{\circ} \mathrm{C}$, chill, and weigh until the weight remains.

\subsubsection{Analysis of Glucomannan Levels}

The determination of glucomannan content in tuber flour was conducted by weighing $6 \mathrm{~g}$, dissolving it in 600 $\mathrm{mL}$ of water at $75^{\circ} \mathrm{C}$ on the flour, then adding $0.6 \mathrm{~g}$ of aluminum sulfate salt, and stirring for 35 minutes to one hour. The solution obtained was filtered using a filter cloth. The filtrate obtained was mixed with isopropyl alcohol in a ratio of 1: 1 and stirred to coagulate the glucomannan. Glucomannan was clumped in jelly-like shape, pure white. After being completely separated, the glucomannan was dried to constant weight.

\subsubsection{Protein Level Analysis}

Weighed $0.1-0.5 \mathrm{~g}$ of tuber flour, is need to put in a Kjedhal flask, then added $2 \mathrm{~g}$ of selen mixture and $25 \mathrm{~mL}$ of concentrated $\mathrm{H}_{2} \mathrm{SO}_{4}$. The material was heated over an electric heater or a fire burner until it boiled, and the solution became clear greenish (about 2 hours). Then let it cool, then dilute it and put it in a $100 \mathrm{~mL}$ volumetric flask, precisely until the line marks. The solution was pipette $5 \mathrm{~mL}$ and put into the distiller, $5 \mathrm{~mL}$ of $30 \% \mathrm{NaOH}$ was added, and a few drops of PP indicator too. The distillation was approximately 10 minutes, using $10 \mathrm{~mL}$ of $2 \%$ boric acid mixed with the container indicator. Is needed to rinse the tip of the cooler with distilled water-titration with $0.01 \mathrm{~N} \mathrm{HCl}$ solution. The blank was determined.

\subsubsection{Lipid Content Analysis}

It should be weighed carefully $2 \mathrm{~g}$ of the sample, put it into a paper tube lined with cotton. Then, it is needed to plug the paper tube containing the sample with cotton, dry it in the oven at a temperature of not more than $80^{\circ} \mathrm{C}$ for about 1 hour, then put it in the soxhlet fat flask, which has determined weight-extracting with hexane for approximately 6 hours; distill the hexane and dry the fatty extract in the oven at $105^{\circ} \mathrm{C}$; chill weigh and repeat drying until the weight is constant.

\subsection{Data Analysis Techniques}

The data analyzed in this study were all data produced on unfermented porang flour and fermented porang flour for 8 hours, 10 hours, and 12 hours. Data analysis used mean \pm SD

\section{RESULT AND DISCUSSION}

There were varied results for each macronutrient analyzed. The results of macronutrients which have been fermented mostly experienced a decrease in value such as carbohydrates, starches, glucomannan, and lipids; but there were also those that have increased in value, of fiber and protein. 
The decrease in the value of carbohydrates, starch, and glucomannan may occur because in the fermentation process the starch was broken down by the activity of microorganisms into simple sugars accompanied by glucomannan granules release[13].

The decrease in carbohydrate value occurred in 10 hours of fermentation with $71.68 \%$ carbohydrate content, it is in line with the previous studies conducted on suweg flour (Amorphophallus campanulatus) with fermented carbohydrates content of $81.7 \%$ and without fermentation of $82.12 \%$ [8]. However, it is different from previous research conducted by Subekah Nawa Kartikasari, et al., 2016 [12], the results of 24-hour fermented starch were $93.01 \%$ and $91.54 \%$ for unfermented starch. In this study, there was a decrease in content of starch starting from fermentation for 8 hours with a starch content of $48.91 \%$ compared to before fermentation which was $54.2 \%$. Research results with different results also occurred in lipid levels. Lipid levels in this study decreased in which before fermentation, it was $4.9 \%$, after 8 hours of fermentation the lipid levels were $1.05 \%$. However, previous studies on Amorphophallus campanulatus lipid levels fermented $\mathrm{LAB} 0.46 \%$ and without $\mathrm{LAB}$ fermentation which was $0.38 \%$ [8].

The increase in the value of fiber and protein occurs because the longer the fermentation time, the more LAB (lactic acid bacteria) accumulates fiber and protein[15][12].

The increase in fiber value was due to the influence of fermentation which was in line with the results of research conducted by Winarsi, et al, 2019 [15]. In the study, there was an increase in fiber by $6.29 \%$ with a 24 hour fermentation time. In this research, the highest fiber value was obtained during the fermentation time of 12 hours with a fiber value of $9.51 \%$. An increase in protein value in this study is in line with the previous research administered by Dian Ratih Laksmitawati, et al., 2018 [8] there is a difference in protein content of LAB fermented suweg flour (Amorphophallus campanulatus) that was $7.41 \%$ and without LAB fermentation $6.05 \%$. In this study, the highest increase occurred with a fermentation time of 10 hours with $10.7 \%$ for the protein content.

\subsection{Carbohydrat Levels}

Carbohydrate levels using a rough calculation, in fermented porang tubers for 8 and 10 hours encountered the decrase. The decrease was since carbohydrates were used as a food source for bacteria. Supported by the statement from Haryani et al., 2019 [11], the reduction of carbohydrates occurred because microorganisms utilize their energy needs by breaking down organic matter, caused by amylase and lipase enzymes working in breaking down starch and fat from the substrate so that the organic matter content decreased during fermentation. The effect of porang tuber flour treatment according to fermentation time on the carbohydrate content can be seen in Table 1.
Table 1. Carbohydrate Levels

\begin{tabular}{|l|l|l|}
\hline No & Fermentation time & Value \\
\hline 1 & Pre Fermentation & 80.16 \\
\hline 2 & 8 hours & 76.91 \\
\hline 3 & 10 hours & 71.68 \\
\hline 4 & 12 hours & 73.21 \\
\hline \multicolumn{2}{|c|}{ \pm SD } & 3.80 \\
\hline
\end{tabular}

\subsection{Starch Levels}

From the results, it was discovered that the longer the fermentation took place, the more the starch content of fermented porang tubers increased. The starch content in fermented porang flour for 10 hours tended to decrease compared to fermented porang flour in 8 hours and 12 hours. It decrease occurred because, in the fermentation process, there was a breakdown of starch into simple sugars by microorganisms' activity 12]. Anggraeni and Yuwono, 2014[13] stated that during fermentation, there was a microbial activity causing starch degradation accompanied by the formation of simple sugars utilized for energy in growth and activity. The starch degradation led to a decrease in starch content (Table 2).

Table 2. Starch Levels

\begin{tabular}{|l|l|l|}
\hline No & Fermentation time & Value \\
\hline 1 & Pre Fermentation & 54.23 \\
\hline 2 & 8 hours & 48.91 \\
\hline 3 & 10 hours & 47.99 \\
\hline 4 & 12 hours & 49.04 \\
\hline \multicolumn{2}{|c|}{ \pm SD } & 2.83 \\
\hline
\end{tabular}

\subsection{Fiber Content}

The results of fermented crude fiber analysis obtained an increase; it happened because during the fermentation of LAB, it degraded the starch, causing an increase in the breakdown of fibrous material particles [12]. The longer the fermentation time was, the more cellulose fibers were produced to become fiber section [14]. In a study conducted by Winarsi et al., 2019 [15], it was explained that the longer the fermentation, the more time for LAB (lactic acid bacteria) to produce polysaccharide sheaths to accumulate more fiber.

Table 3. Fiber Levels

\begin{tabular}{|l|l|l|}
\hline No & Fermentation time & Value \\
\hline 1 & Pre Fermentation & 4.96 \\
\hline 2 & 8 hours & 7.08 \\
\hline 3 & 10 hours & 9.04 \\
\hline 4 & 12 hours & 9.51 \\
\hline \multicolumn{2}{|c|}{ \pm SD } & 2.07 \\
\hline
\end{tabular}

\subsection{Glucomannan Levels}

The results of glucomannan levels decreased at 10 hours of fermentation. A decrease occurrade because each glucomannan granule was covered with starch [16]. 
However, at 12 hours fermentation, there was an increase since the microorganisms began to degrade starch. The statement is also strengthened by research [13] that during fermentation, there is a microbial activity that causing starch degradation accompanied by the formation of simple sugars which used for energy in growth and activity. Starch removal can release glucomannan granules which causes the concentration increases. The enzyme concentration, temperature, and hydrolysis time affect the purity of glucomannan. At 12 hours of fermentation with high concentrations, the highest glucomannan levels were achieved [16].

Table 4. Glucomannan Levels

\begin{tabular}{|l|l|l|}
\hline No & Fermentation time & Value \\
\hline 1 & Pre Fermentation & 28.67 \\
\hline 2 & 8 hours & 3.15 \\
\hline 3 & 10 hours & 2.61 \\
\hline 4 & 12 hours & 3.6 \\
\hline \multicolumn{2}{|c|}{ \pm SD } & 12.77 \\
\hline
\end{tabular}

\subsection{Protein Content}

From the results, it can be seen that the longer the fermentation was, the higher the protein content was. It happened because microbes hydrolyze complex proteins entered into free amino acids or simpler peptides in the presence of proteolytic enzyme activity during the fermentation process. futhermore, the increase in microbial biomass during the fermentation process was in line with the secretion of several extracellular enzymes (dissolved proteins) and single-cell proteins. Therefore, dissolved protein content increased[17]. In a study conducted by Kartikasari et al., 2016 [12] it was asserted that increased protein levels could come from lactic acid bacteria, producing protein if the microbes used remain and mix with the mass of the substrate, so the higher the protein, the higher the pycnolytic enzyme activity.

Table 5. Protein Content

\begin{tabular}{|l|l|l|}
\hline No & Fermentation time & Value \\
\hline 1 & Pre Fermentation & 5.77 \\
\hline 2 & 8 hours & 7.1 \\
\hline 3 & 10 hours & 10.7 \\
\hline 4 & 12 hours & 10.3 \\
\hline \multicolumn{2}{|c|}{ \pm SD } & 2.41 \\
\hline
\end{tabular}

\subsection{Lipid Levels}

The results of the Lipid content obtained on the length of fermentation increased. It happened because of a decrease in the number of lactic acid bacteria, causing the lipase enzyme activity decrease [18]. Increased Lipid levels occured because microorganisms produce microbial oil during the fermentation process, where microorganisms were other living cells capable of producing lipids or fat [19].
Table 6. Lipid Levels

\begin{tabular}{|l|l|l|}
\hline No & Fermentation time & Value \\
\hline 1 & Pre Fermentation & 4.96 \\
\hline 2 & 8 hours & 1.05 \\
\hline 3 & 10 hours & 1.1 \\
\hline 4 & 12 hours & 1.36 \\
\hline \multicolumn{2}{|c|}{ \pm SD } & 1.89 \\
\hline \multicolumn{2}{|c|}{}
\end{tabular}

\section{CONCLUSION}

The results of the porang tuber fermentation (Amorphophallus muelleri Blume) with Lactobacillus bulgaricus bacteria contain carbohydrates, starch, fiber, glucomannan, protein, and Lipid. The results of the research on macronutrient content before and after fermentation for 8 hours, 10 hours and 12 hours for carbohydrates were mean \pm SD 3.80 ; starch mean \pm SD 2.83; fiber mean \pm SD 2.07 ; glucomannan mean \pm SD 12.77; protein mean \pm SD 2.41; and Lipid mean \pm SD 1.89.

\section{REFERENCES}

[1] Sumarwoto (2005) 'Iles-iles (Amorphophallus muelleri Blume); Description and Other Characteristics', Biodiversitas, 6(3), pp. 185-190. doi: 10.13057/biodiv/d060310.

[2] Richana, N. (2019) Araceae dan Dioscorea. print II. Edited by W. Waridah. Bandung: Nuansa Cendekia Publisher.

[3] Hidayah, N., Suhartanto, M. R. and Santosa, E. (2018) 'Growth and Production Iles-iles (Amorphophallus muelleri Blume) from Different of Cultivation Techniques', Bul. Agrohorti, 6(3), pp. 405-411. doi: 10.1017/CBO9781107415324.004.

[4] Wigoeno, Y. A., Azrianingsih, R. and Roosdiana, A. (2013) 'Analysis of Glucomannan Levels in Porang Bulbs (Amorphophalus muelleri Blume)' using reflux Condenser, Biotropika : Journal of Tropical Biology, 1(5), pp. 231-235.

[5] Nissa, C. and Madjid, I. J. (2016) 'The Potential og Glucomannan Derived from Konjac Flour as an antiobesity agent in rats induced by high fat diet', Jurnal Gizi Klinik Indonesia, 13(1), pp. 1-6.

[6] Laksmitawati, D. R., Marwati, U. and Indriani, V. (2019a) 'Macronutrient Content and Glycemic Index Value of Suweg Tuber (Amorphophallus companulatus) with and without Fermentation', Jurnal Ilmu Kefarmasian Indonesia, 17(1), pp. 40-45.

[7] Fadlallah, O. E., Tinay, A. H. El and Babiker, E. E. (2010) 'Biochemical Characteristics of Sorghum Flour Fermented and/or Supplemented with Chickpea Flour', International Journal of Nutrition and Food Engineering, 4(1), pp. 40-44.

[8] Laksmitawati, D. R., Marwati, U. and Indriani, V. (2019b) 'Effect of Fermentation of Suweg Tubers (Amorphophallus campanulatus) on Macronutrient Levels and Glycemic Index Value of Mice', Kartika : Jurnal Ilmiah Farmasi, 6(1), pp. 21-28. doi: 10.26874/kjif.v6i1.124.

[9] Suhaili, A., Prasetyawan, S. and Sutrisno (2013) 'Determination of Optimum Condition for Fermentation using Lactobacillus bulgaricus in Making Fermented Suweg (Amorphophallus camanulatus) Flour', Kimia Student Journal, 2(1), pp. 463-469. 
[10] Luh, M. (2011) 'Benefits and Safety of Fermantation for Health (Tinjauan dari Aspek Ilmu Pangan', JPTK, UNDIKSHA, 8(1), pp. 53-58.

[11] Haryani, K. et al. (2019) 'Making Vermicelli from Modified Sorogum Flour Using Lactobacillus Bulgaricus, 14(1), pp. 27-34. doi: 10.32497/rm.v14i1.1451.

[12] Kartikasari, S. N., Sari, P. and Subagio, A. (2016) 'Characterization of Chemical Properties, Amylograpic Profiles (RVA) and Granular Morphology (SEM) of Biologically Modified Cassava Starch', Jurnal Agroteknologi, 10(1), pp. 12-24.

[13] Anggraeni, Y. P. and Yuwono, S. S. (2014) 'Effect of Natural Fermentation in Chips of Sweet Potato (Ipomea batatas) Against Physical Properties of Wheat Sweet Potato', Pangan dan Agroindustri, 2(2), pp. 59-69.

[14] Krabi, R. E. et al. (2015) 'Screening of Lactic Acid Bacteria as Potential Starter for the Production of Attiéké, a Fermented Cassava Food', Journal of Faculty of Food Engineering, XIV(1), pp. 21-29.

[15] Winarsi, H. et al. (2019) 'Fermentation Of Lactic Acid Bacteria Improving Phenolic and Fiber Content of Red Kidney Bean Sprouts Milk (Phaseolus Vulgaris
L.) Yogurt, A Functional Drinks For Obesity', Jurnal Gizi dan Pangan Soedirman, 3(1), pp. 64-75.

[16] Wardhani, D. H. et al. (2016) 'Enhancing the Quality of Glucomannan from Amorphophallus oncophyllus Enzymatically with a-Amylase', Inovasi Teknik Kimia, 1(1), pp. 71-77.

[17] Martono, Y., Danriani, L. D. and Hartini, S. (2016) 'The Effect of Fermentation on Protein Content and Amino Acids of Fortified Dried-Cassava FlourSoybean (Glycine Max (L)) Flour', Agritech Journal, 36(1), p. 56. doi: 10.22146/agritech.10684.

[18] Purwijantiningsih, E. (2016) 'Influence of Prebiotics Variety on The Quality of Probiotic Yogurt', Journal of Biota, 12(3), pp. 177-185. doi: 10.24002/biota.v12i3.652.

[19] Yuniasari, R., Hartini, S. and Cahyanti, M. N. (2017) 'Profil Protein dan Lemak Selama Proses Fermentasi Tepung Singkong dengan Biakan Angkak', in National Chemistry Seminar 2017, pp. 132-138.

[20] SNI (1992) How to test food and beverages, SNI (National Standard of Indonesia) 